\title{
Distant Leadership Under Stress
}

\author{
Yan Xiao \\ F. Jacob Seagull \\ Colin F. Mackenzie \\ University of Maryland, Baltimore \\ Katherine Klein \\ Jonathan Ziegert \\ University of Maryland, College Park \\ Thomas Scalea \\ University of Maryland, Baltimore
}

Basic Research Office

Paul A. Gade, Chief

U.S. Army Research Institute for the Behavioral and Social Sciences 5001 Eisenhower Avenue, Alexandria, Virginia 22333-5600

July 2003

\begin{tabular}{ll}
\hline Army Project Number & Personnel, Performance and \\
20161102B74F & Training
\end{tabular}

Approved for public release; distribution unlimited

iii 